Name of the author: Christine Yi Lai Luk

Title: Radium, biophysics, and radiobiology: tracing the history of radiobiology in twentieth-century China

Affiliation: the University of Hong Kong

Address: Hong Kong Institute for the Humanities and Social Sciences, the University of Hong Kong, Pokfulam Road, Hong Kong

\begin{abstract}
:
Radiobiology assesses the biological hazards of exposure to radioactive substances and nuclear radiation. This article explores the history of radiobiology in twentieth-century China by examining the overlapping of radium research and biophysics, from roughly the 1920s Nationalist period to the 1960s Communist period; from the foreign purchase of radium by the Rockefeller Foundation's China Medical Board during the Republican era, to the institutional establishment of radiobiology as a subset of biophysics in the People's Republic. Western historiography of radiobiology highlights the connection between the military development of nuclear weapons and the civilian use of radiation in biology, as well as the international export of radioisotopes and nuclear reactors. Considering the exclusion of China from Western atomic diplomacy, I argue that the study of the Chinese history of bomb-making and radiobiology is necessary not just to fill an existing knowledge gap, but more importantly to elucidate the influence of the Chinese nuclear weapons program and Cold War atomic politics on Chinese life-science enterprises. Through examining the formational history of the radiobiology program in China, I hope to shed light on the implications of the atomic age for Chinese biology in the twentieth century.
\end{abstract}

Keywords: radiobiology, biophysics, China, nuclear weapon, radioactivity and radiation 


\title{
Radium, biophysics, and radiobiology: tracing the history of radiobiology in twentieth-century China
}

\begin{abstract}
Radiobiology assesses the biological hazards of exposure to radioactive substances and nuclear radiation. This article explores the history of radiobiology in twentieth-century China by examining the overlapping of radium research and biophysics, from roughly the 1920s Nationalist period to the 1960s Communist period; from the foreign purchase of radium by the Rockefeller Foundation's China Medical Board during the Republican era, to the institutional establishment of radiobiology as a subset of biophysics in the People's Republic. Western historiography of radiobiology highlights the connection between the military development of nuclear weapons and the civilian use of radiation in biology, as well as the international export of radioisotopes and nuclear reactors. Considering the exclusion of China from Western atomic diplomacy, I argue that the study of the Chinese history of bomb-making and radiobiology is necessary not just to fill an existing knowledge gap, but more importantly to elucidate the influence of the Chinese nuclear weapons program and Cold War atomic politics on Chinese life-science enterprises. Through examining the formational history of the radiobiology program in China, I hope to shed light on the implications of the atomic age for Chinese biology in the twentieth century.
\end{abstract}

Keywords: radiobiology, biophysics, China, nuclear weapons, radioactivity and radiation 


\section{Introduction}

On 16 October 1964, the People's Republic of China (PRC) detonated its first atomic bomb. Between 1964 and 1996, the PRC conducted a total of 45 nuclear weapons tests, of which 23 were above ground, atmospheric nuclear tests in the westernmost province of Xinjiang, inhabited mostly by an ethnic minority, the Uyghurs (Reed 2008). ${ }^{1}$ In a 2009 article in Scientific American, an investigative journalist revealed the untold biomedical damage suffered by the Uyghurs collectively exposed to the radiation poisonings from China's nuclear blasts since the 1960s (Merali 2009). The title of the report, "Blasts from the past" aptly describes the nature of the affliction amongst the victims of radioactive fallout. Alongside victims' accounts, a comprehensive understanding of "Blasts from the past" requires also the complementary narrative of the scientists who were the main players in these nuclear programs, from the detonation of the deadly atomic bombs to the application of nuclear science and technology.

Part of the story of how Chinese nuclear scientists and policymakers built their first atomic bomb has been supplied by John Lewis and Xue Litai, who described together the policy contexts of arms control and nuclear weaponry with the technological challenges of uranium mining, the production of fissionable materials, and the construction of nuclear facilities (Lewis and Xue 1988). Building upon their impressive scholarship on China's nuclear studies, this article offers the perspective of the biomedical participants - the biophysicists - in the bomb-making program. The account of biophysicists in the atomic program can be considered as a sequel to the bomb-making episode in two ways. Firstly,

\footnotetext{
${ }^{1}$ In another account, the total number of nuclear weapon tests conducted by China was reckoned to be 44 , of which 22 were atmospheric and 22 were underground tests. See "Table 1.1 Nuclear weapon tests in the world," Takada (2004), on p. 10.
} 
unlike nuclear physicists and engineers, biophysicists' role in the bomb program was marginal as they were not the principal architects of the bomb. Although scientists of all stripes participated in the atomic bomb program, it was primarily those involved in physical science and nuclear engineering that were the sine qua non in the design and manufacture of the bomb. Secondly, on the disciplinary level, radiobiology - the broadly conceived discipline dedicated to the study of biological risks arising from human and environmental exposure to radiation and radioactive materials - is in many ways an applied branch of nuclear science. Historians of biology have drawn attention to the way in which the discipline of radiobiology emerged largely from the work on nuclear bomb (Krige 2006; Creager and Santesmases 2006; Creager 2002, 2006, 2014). Taking radioisotopes as an example, the cyclotron machines responsible for generating artificial radioisotopes for civilian application were initially used to accelerate subatomic particles for military purposes. In short, the beneficial applications of nuclear science in postwar Europe and America owed their existence to the development of the destructive technology of nuclear weaponry.

Scholarship in the history of biology has offered case studies of the postwar development of radiobiology in Western countries such as England (de Chadarevian 2006), France (Gaudilliere 2006), Spain (Santesmases 2006), and the US (Rader 2006). These authors addressed the critical role of the state in providing the necessary human and financial incentives that underline these national radiobiological infrastructures. While government agencies had a central role in sponsoring the national nuclear projects, there was also a need for the transnational regulation of radiation-related knowledge. The circulation of radioisotopes from the US to the rest of the world is a politically contested 
project that provokes international controversy (Creager 2002, Krige 2006). Couched in the benign terminology of the "peaceful uses of atomic energy," the Atoms for Peace program conceals the American ideological quest for global dominance through science and technology transfer (Krige 2008).

Despite a growing body of literature assessing the reception and development of nuclear technology and applications in non-Western countries (Dimoia 2010; Leslie 2015; Mateos and Suárez-Díaz 2015), the context in which non-energy applications of nuclear science developed in China is not particularly well understood. The Chinese case is peculiar and worth studying for two reasons. Firstly, the detonation of the first atomic bomb in China took place in 1964 - nineteen years after the United States bombed Hiroshima and Nagasaki, and seventeen years after the former USSR detonated its first atomic bomb. The conclusion of the Manhattan project in 1946 provided the technical cornerstone for Washington to promulgate the non-military "Atoms for Peace" policy in 1953 and at the Geneva conference in 1955, to which China was not invited being neither an ally nor a perceived threat to the US monopoly of nuclear supremacy (Krige 2008). In fact, Chinese leaders had not resolved to launch a domestic nuclear weapons program until the end of the Korean War. ${ }^{2}$ The heavy casualties resulting from this war convinced the guerrilla-minded leaders of an urgent need to produce and develop strategic nuclear weapons. ${ }^{3}$ Secondly, China was not on the receiving end of President Eisenhower's Atomsfor-Peace diplomacy, unlike the East Asian allies in America's sphere of influence. While

\footnotetext{
${ }^{2}$ Wang Zuoyue recently suggested that by 1952 the Chinese leaders had begun to plan for a nuclear weapons program. See Phalkey and Wang (2016).

${ }^{3}$ Although Chairman Mao approved the construction of strategic nuclear weapons, he remained skeptical of the relative priority and significance of advanced technology over what he considered to be "the hallowed doctrine of the People's War." He maintained that, "The outcome of war will be decided not by the atomic bomb, but by conventional weapons" (Lewis and Xue 1994: 89).
} 
Japan, South Korea, and Taiwan received American-manufactured reactors and radioisotopes (Dimoia 2010), Cold War politics blocked the international flow of atomic knowledge and materials from the First World to the Second World. The PRC was thus excluded from the Atoms-for-Peace framework and Chinese scientists did not benefit from the US international distribution of nuclear knowledge and equipment. For these two reasons, the bomb-initiated narrative of radiobiology is going to unfold quite differently in the Chinese case.

That China lagged behind the US and the former USSR in the pursuit of nuclear weaponry is known, but the impact of this near two-decade lapse on civilian science is more obscure. State-sanctioned histories of the "Two Bombs, One Star" project, the Chinese equivalent of the Manhattan Project, usually celebrate the political correctness of the program and the historical inevitability of the leadership of the Chinese Communist Party (Dong 2007, Li 2000, Bo 2001). Outside of China, foreign observers who followed the development of the Chinese nuclear program and device tests tend to emphasize the speed with which the Chinese achieved the same technological feats as were achieved in the West, under enormous hardship and material shortages. ${ }^{4}$ The triumphalist narratives of "Two Bombs, One Star" offered by both domestic and foreign commentators tend to overlook the broader impacts of the bomb program and nuclear devices. As in other countries, nuclear science originated in wartime as a weapon of mass destruction, but gradually evolved into a device of mass salvation after the war. Western historiographies of

\footnotetext{
${ }^{4}$ For example, in a recent article chronicling the development of Chinese nuclear weapons tests between 1964 and 1996, the author, Thomas Reed, former secretary of the Air Force, described the rapid pace of the Chinese pursuit of high-end nuclear weapons. Whereas it took the US more than seven years to proceed from the initial atomic bomb test to a thermonuclear blast, it took the Chinese less than three years to make the same transition; whereas the UK fired nine fission tests before conducting its first fusion experiment, it only took the Chinese three tests prior to launching the same experiment. See Reed (2008).
} 
the peacetime development of atomic science and technology have offered many useful insights into the ways in which Eisenhower's atomic diplomacy served as an explanatory framework for the transition of nuclear policymaking from military weapon research to civilian radioactive biomedical research. John Krige has critically examined the politics of atomic energy programs by suggesting that Eisenhower's "Atoms-for-Peace" discourse is inherently tied to the postwar American quest for global supremacy (Krige 2005, 2008). As Krige unambiguously put it, "Atoms for Peace was thus an attempt to maintain US nuclear superiority" (Krige 2006: 164). Yet Eisenhower's atomic diplomacy is not very relevant for understanding the history of radiobiology in China, since it was marginal to the development of Chinese radiobiology, as analyzed above. To understand the origins of radiobiology in China, we need to go beyond the Atoms-for-Peace framework and turn to the domestic discourse in radiobiology in China, as it unfolded within the larger context of Cold War political rivalry. ${ }^{5}$

In tracing the development of radiobiology in twentieth century China, I will first examine the import of radium into Republican China under the auspices of the Rockefeller Foundation. The prewar supply of radium to China in the late 1910s and early 1920s can be considered as an overture to the postwar ascendancy of radiobiology. Next, I describe the postwar institutional development of nuclear science and technology under which radiobiology is situated. To help readers grasp the domestic contexts of Chinese scientific and educational institutions, I give a brief overview of the organization of scientific and

\footnotetext{
${ }^{5}$ Although China was outside the America's sphere of influence, it was once an entrenched part of the Communist bloc. Before the Sino-Soviet split in 1959, the USSR had offered substantial assistance to China in areas of missile research and bomb making. Yet, all Soviet scientists and teaching materials were recalled and taken away respectively from China by June 1959. Thus, the first Chinese nuclear device was codenamed "Mission 596" to commemorate the June 1959 Soviet "betrayal" of their Chinese comrades.
} 
technological enterprises in the PRC, particularly the leading role of the Chinese Academy of Sciences (CAS). Within the CAS umbrella, my focus is placed on the efforts of the Institute of Biophysics at the Chinese Academy of Sciences (IBP-CAS) to support radiobiology. Not only did IBP-CAS supply manpower and equipment to the radiobiology research team, leading Chinese biophysicists such as Bei Shizhang also actively solicited national attention to this newfound discipline by organizing national conferences and workshops on the clinical application of nuclear science and technology. Relying on archival sources from the University of Science of Technology of China (USTC), I analyze the connection between biophysics and radiobiology by correlating the radiobiology coursework at USTC with the radiobiological taskforce at IBP-CAS. The article ends with a note on the historiographical significance of radiobiology to cast light on the contemporary debate about radiation hazards from last century's nuclear blasts.

\section{Before radiobiology: radium in Republican China}

In the first decade of the twentieth century, the powerful radioactive element radium was a common experimental tool in life-sciences research on radiation. The intersection between radium and the life sciences during this period has been considered by Luis Campos, who suggested that radium-related metaphors and stories constitute a "prehistory of radiobiology" (Campos 2015: 8). His study identified the metaphorical and metaphysical associations of radium with the concept of 'half-life' and 'half-living' before the widespread utilization of reactor-generated ionizing radiation in biomedical and genetic research. Following Campos' vivid account of radium in the historiography of twentieth- 
century biology, it seems appropriate to explore the presence of radium in modern China, as a point of entry into the history of Chinese radiobiology.

Radium reached China in the late 1910s and early 1920s via the Rockefeller Foundation. Archival records showing the earliest arrival of radium in China set the date to 1919: "It would be very difficult for us to find records of any purchases of radium for the Peking Union Medical College prior to $1919 .{ }^{\circ}$ Despite formal requests from the China Medical Board (CMB), ${ }^{7}$ the supply of radium was insufficient to match China's domestic demand. By 1921, the quantity of radium purchased from the Pittsburgh Radium Company was 13.4 milligrams, but it was reckoned that at least 100 milligrams of radium was needed for ordinary use at the PUMC. ${ }^{8}$ To meet this growing demand, in the fall of 1922 , a stock of 100 milligrams of radium was sent to Peking. After accounting for some accidental loss, a near 99.34 milligrams of radium was found at PUMC. But when asked about the stock figure of radium at PUMC, Roger Greene was under the impression that "I am a little surprised to find no records indicating an amount larger than this at the College. Offhand, I thought they had about 190 milligrams but apparently my impression is erroneous." 9

From the 1930s onwards, X-ray gradually replaced radium as the common medium for studying the genetic effects of radiation, but the popularity of radium persisted. In a letter dated 17 October 1930 from Roger Greene, CMB director, to secretary Margery Eggleston, he wrote: "we have for a long time felt hampered by the lack of a sufficient supply of radium to enable the various hospital services interested to secure prompt and

\footnotetext{
${ }^{6}$ R. C. Dean to Margery K. Eggleston, 9 March 1928, Rockefeller Archive Center (RAC), China Medical Board Inc. (CMB Inc.) Collection, Research Group (RG) IV2B9, Box 136, Folder 978.

${ }^{7}$ For more information on the relationship between CMB and PUMC, see Rosenbaum (1988).

8 "Purchase of Radium," 3 December 1921, RAC, CMB Inc. Collection, RG IV2B9, Box 136, Folder 978.

${ }^{9}$ R. C. Dean to Margery K. Eggleston, 9 March 1928, RAC, CMB Inc. Collection, RG IV2B9, Box 136, Folder 978.
} 
thorough treatment of those cases which were likely to benefit from the application of radium." ${ }^{10}$ Radium was appealing to $\mathrm{CMB}$ at the Rockefeller Foundation partly because the emanation from radium salts could be applied to surgical operations and tissue treatment, thus making this radioactive element valuable to medical teaching and clinical study. The shortage of radium persisted after the Pacific War ended in 1945. In 1946, Mary E. Ferguson, the long-time administrator at PUMC and chronicler of the institutional history of CMB and PUMC (Ferguson 1970), noted:

\begin{abstract}
One other matter which is of great concern to us is the whereabouts of 25 milligrams of radium which was removed from our department of radiology and which is believed to have been taken to Tokyo. This is of course intrinsically very valuable but also it is of great importance to our hospital when the time comes that we can reopen to have the radium available for treatment. At present there is no radium nearer than Shanghai and North China needs this supply badly. ${ }^{11}$
\end{abstract}

Ferguson's urgent tone conveyed the enormous value of radium in the context of postwar China. Not only was the missing radium of great concern to the PUMC from which it was stolen, Ferguson believed that the radioactive element would assist in the treatment of wounded soldiers and citizens at China's hospitals. Her suspicion that Tokyo was the destination for the stolen radium can be understood in the aftermath of the Second Sino-

\footnotetext{
10 “Radium,” R. S. Greene to M. K. Eggleston, 17 October 1930, RAC, CMB Inc. Collection, RG IV2B9, Box 136, Folder 978.

11 “Excerpt Miss Ferguson to Major L. R. Sickman,” Peiping, China, 3 February 1946, RAC, CMB Inc. Collection, RG IV2B9, Box 136, Folder 978.
} 
Japanese War (1937-1945), while her emphasis on Shanghai and North China draws attention to the imminent civil war between 1946 and 1949, after which the Nationalist Party led by generalissimo Chiang Kai-Shek retreated to Taiwan. The domestic radium supply and demand therefore corresponded to China's historical contingencies before and after the war.

\section{Nuclear science and technology in Communist China}

The Chinese Communist Party, sometimes dubbed "the Chinese Bolsheviks" (Luk 1990) came to power in 1949. Despite the unique Chinese experience of the bolshevization of Chinese communism, some ideological commonalities connect the Chinese communists with the Soviet Bolsheviks, not least of which was a shared belief in the transformative power of science and technology to create a modern and industrial society. Like their Russian counterparts, the Chinese revolutionary leaders also held science and technology in high regard. Although some radical leaders cast doubt on the political loyalty of some scientists and engineers, a strong support system was provided to drive the development of science and technology for modernizing the country. A centralized system topped by the Chinese Academy of Sciences (CAS) was introduced to administer the policies and research goals in science and technology. Major CAS institutions and university facilities in the area of nuclear science and technology were reported by the US Nuclear Science Delegation visiting the PRC in 1978, as part of the Committee on Scholarly Communication with the PRC (Bromley and Perrolle 1980). As nuclear science was closely related to the nuclear weapons program, this scientific branch enjoyed high policy priority. 
This is evident in the release of an influential national policy document "Outline of a LongTerm Plan for the Development of Science and Technology, 1956-1967" (known as the "twelve-year science plan"), which placed a heavy emphasis on the development of domestic nuclear science infrastructure. Wang Zuoyue (2015) recently assessed the politics of the "twelve-year science plan" and contended that the plan was more a result of political struggles and compromises among political leaders, and between party leaders and scientific elites, than a unanimous consensus arising from a well-informed constituency. Building on Wang's broader argument that the making of Chinese science and technology policy was jointly shaped by the Cold War geopolitics and domestic political division, I investigate the emergence of radiobiology in the PRC by considering both international politics and domestic strife in shaping the disciplinary character of radiobiology in relation to nuclear science.

It is noteworthy that the growth of radiobiology is inseparable from the military pursuit of nuclear weapons. The strategic development of nuclear weapons offered a policy justification for advancing nuclear science upon which non-energy applications of nuclear science such as radiobiology and radiochemistry are built. It is within the context of nuclear infrastructure that one can begin to discuss the biochemical use of radiation as an applied field of nuclear science. In the twelve-year science plan, radiobiology and radiochemistry were subsumed under the strategic weapons framework involving the construction of atomic bombs and missiles. Zhang Zhihui and Liu Pei have recently examined the history of radiochemistry as a discipline in the PRC (Zhang and Liu 2015). As a specialty concerned with the collection of radioactive debris after nuclear explosion (Reed 2008), radiochemistry thrived in the PRC, mostly as a service tool for the state-led nuclear 
industry rather than as an independent academic discipline. Similarly, radiobiology was also founded as part of the Chinese nuclear program under the Institute of Modern Physics in 1950. Renamed the Institute of Atomic Energy (IAE) in 1958, this institute was jointly administered by CAS and the Second Ministry of Machine Building, the ministry responsible for developing nuclear weapons. The IAE was run by notable Chinese physicists such as Qian Sanqiang, IAE's founding director and later vice president of CAS; Zhao Zhongyao, widely regarded as the father of nuclear physics in China and the founding deputy director of IAE; Wang Ganchang, director of IAE and vice minister of the Second Ministry of Machine Building. In this physicist-dominated nuclear domain, the father of biophysics in China, Bei Shizhang, was invited to set up a radiobiology unit under the aegis of the IAE. ${ }^{12}$

Within the IAE, the initial mission of the radiobiology unit was to measure and detect background radiation in the environment. ${ }^{13}$ Recording doses of naturally occurring radiation above ground was important because such data enabled a more accurate understanding of the hazards of man-made radiation. For the Chinese radiobiologists, their first task was to conduct a pre-bomb nationwide survey of background radiation. Surveying agricultural produce, aquatic foodstuffs, soil and water samples collected from major cities such as Shanghai, Qingdao, Guangzhou, and Xiamen, the Chinese radiobiologists cooperated with zoologists, marine biologists, microbiologists, and geophysicists from other institutes to complete the task (IBP-CAS 2012).

\footnotetext{
${ }^{12}$ I have explored Bei Shizhang's role as the founding father of biophysics in contemporary China. See Luk (2015a), chapter 2.

${ }^{13}$ Sources of background radiation are cosmic rays, sunlight, radon gas, and radioactive elements in the earth's crust such as uranium and thorium. This naturally occurring radiation accounts for over $80 \%$ of humans' radiation exposure. See EPA (2007).
} 
As soon as the Institute of Biophysics was founded in 1958, Bei Shizhang constructed a radiobiology research group within the IBP framework to offer an institutional home for radiobiology. To align with the military needs of radiation management, the radiobiology group was divided into five teams: 1) long-term study of low-dose radiation on monkeys; 2) effects of nuclear fallout on living animals; 3) peaceful application of atomic energy (as in irradiation pasteurization); 4) research and development of dosimeters and other radiation instruments; and 5) research on natural background radiation. Although a biological study of background radiation was present when radiobiology was previously housed in the IAE, such a biological agenda became more pronounced, differentiated and fine-tuned after the IBP took control of radiobiology.

Given this central role of biophysicists in transforming the research direction of radiobiology, one is prompted to ask: why were biophysicists interested in pursuing radiobiology? An obvious answer is that biophysicists in other countries were similarly charged with the task of measuring the biomedical effects of radiation. The Institute of Biophysics in the former USSR was a prime example. The Soviet IBP was one of the earliest institutes in charge of the physiological investigations of nuclear hazards. After the Chernobyl accident in 1986, the Radiation Medicine Center of the IBP in Moscow sent medical inspection teams to Chernobyl to conduct physical examinations of the victims (Bauer et al. 2005, Takada 2004). In the aftermath of the World War II, American biophysicists were given unprecedented opportunities to study a wide range of biological research questions related to light and radiation. As historian of biophysics Nicholas Rasmussen noted, “The work of radiologists, biologists, and physicists on the physiological and hereditary effects of radiation upon living things had fallen under biophysics by the 
1930s." (Rasmussen 2014: 10). But this affinity between biophysics and radiobiology has more to do with the historical circumstances of postwar life sciences rather than a natural inclination of biophysicists to create a radiological knowledge base. Characteristic of how contemporary American history, for example, shaped biophysics and radiobiology is the changing interpretation of radiobiology, a term which acquired a new meaning after World

War II. Radiobiology in postwar America was associated with the biomedical use of artificial radioisotopes rather than naturally occurring radioactive elements like radium, thanks to the abundant supply of atomic pile-generated isotopes after the war. From radium to X-rays to radioisotopes, historians of biology have collectively revealed the changing meanings of radiobiology over time. The content of radiobiology adapted to the evolving military capabilities and policy demands.

To illustrate the shifting understandings of radiobiology in China, and particularly the intersection between radiobiology and biophysics, I trace the development of the biophysics program at the University of Science and Technology of China (USTC) between 1958 and 1964 - a period leading up to the explosion of China's first atomic bomb.

\section{Biophysics and radiobiology at USTC}

Founded in Beijing in 1958, USTC was created primarily as an educational facility for training scientists and engineers for CAS. Although I have examined the USTC's early institutional history and its biophysics program elsewhere (Luk 2015b), my previous analysis did not cover the role of biophysicists in shaping the research direction of radiobiology. Under the guiding principle known as "mission-drive-discipline," new 
departments such as that of biophysics were established at USTC in 1958. Responding to the general requirement that science must serve the practical interests of the state, the department of biophysics offered a list of courses for biophysics, biochemistry, and biointelligence programs. In the 1961 course plan, intended for the bio-intelligence students who were trained to work as intelligence officers, radiobiology was the only biophysicsrelated course in the course catalogs for bio-intelligence majors. ${ }^{14}$ In my previous analysis, I suggested that radiobiology was offered for bio-intelligence students due to its intimate connection with the military-industrial complex in areas of nuclear science and technology. However, it is not very clear how radiobiology served the interests of the military-nuclear program, nor is the distinction between radiobiology and biophysics immediately obvious. Although the original emphasis on nuclear science may well have been spurred by military considerations, the enabling factors for Chinese biophysicists to participate in radiobiological research are not self-evident. Through a discussion of the radiobiology cluster at the biophysics department at USTC, the following section aims at depicting the overlap between biophysics and radiobiology, and their broader connection with China's nuclear configuration within the Cold War setting.

The year 1958 was eventful for Chinese biophysics. A research institute and a teaching department for biophysics were established respectively at CAS and USTC. The co-construction of the IBP-CAS and the biophysics department at USTC was designed to align biophysical teaching with research in the immediate interests of national defense. For example, the coursework in radiobiology was intended to bring classroom learning together

\footnotetext{
${ }^{14}$ For a more detailed description and analysis of the bio-intelligence course plan at USTC, see Luk (2015b), pp. 222-225.
} 
with practical training in order to complete the secret mission with which the IBP had been tasked. Code-named "Mission 21" and under the direct command of the Central Military Commission, this mission was a top secret project devoted to studying the late-onset effects of radiation exposure in animals. Using animals as proxies, the objective of "Mission 21 " was to assess the impact of ionizing radiation generated from nuclear weapons tests on living organisms (IBP-CAS 2012).

To supply the requisite human resources for "Mission 21," several accommodations were made at the USTC biophysics department. In 1960, a radiobiology strand was introduced to the biophysics program. Under the rubric of radiobiology, topics such as "effects of radiation on living organisms," "effects of radiation on environment," and "effects of radiation on plants" were explored in the classroom, while radiobiology fieldwork was conducted by researchers from the Shanghai Institute for Nuclear Research (INR). Unlike the Institute of Atomic Energy in Beijing and the Institute of Modern Physics in Lanzhou, the INR in Shanghai was dedicated not to basic research but to applied studies of nuclear science and technology. Employing specialists in isotopes and radiation chemistry, one of INR's major laboratories was responsible for producing isotopes for biomedical purposes (Bromley and Perrolle 1980). Borrowing the expertise of these radiochemists from the INR, the radiobiology curriculum was supplemented with hands-on instruction outside the classroom. To show what was being taught, let me briefly explain the lecture notes on radiobiology from 1960.

The USTC radiobiology lecture notes of 1960 consisted, as can be seen in Table 1, of 7 units and 36 chapters. What is noteworthy is the emphasis of ionizing radiation throughout the syllabus. Even though the first unit, namely "the physical foundation of 
radiobiology," contains no direct reference to "ionizing radiation," it contained two chapters titled "the production of ionizing radiation and its functions on substance" and "basic concepts of dosimetry of ionizing radiation." Nearly each of the subsequent units in the syllabus dealt with the effects of ionizing radiation. The centrality of ionizing radiation signaled a paradigm shift from the previous focus on background radiation. When the radiobiology team was still embedded amongst the physicists in the IAE, their primary assignment was to study background radiation in the environment, which was mostly weak, non-ionizing radiation with energy levels more or less similar to that of radio waves or visible light (EPA 2007). The changing focus from non-ionizing radiation to ionizing radiation reflects the disciplinary rise of radiobiology, since radiobiology was defined essentially as "the study of the effects of ionizing radiation on living things" (IOM and NRC 2014: 5). Even though biophysicists participated in the pre-bomb environmental study of naturally occurring background radiation, a more distinctive "biological" character became more apparent beginning in or around 1960, as "Mission 21" unfolded and biophysicists were commissioned to examine the impact of ionizing radiation on living organisms.

Meanwhile, environmental studies of background radiation continued to hold sway. As Table 1 shows, the largest unit in the syllabus is unit seven, titled "radiation ecology and toxicology," which comprised 10 chapters and more than 43 topics. This is also the only unit with an opening preface explaining the historical background and research goals of what was called "radiation ecology." The ascendancy of radiobiology was very much dependent on its military applications: one need only take a closer look at the individual topics covered in Table 1, in which the entire chapter 28 was devoted to nuclear weapons 
and part of chapter 29 to exploring the potential damage from continuous nuclear weapons tests. Through the syllabus of radiobiology, one can visualize the parallel and interdependent development of radiobiology teaching and learning and of nuclear weapons tests.

However, this is not the only way in which radiobiology served the interests of the military-nuclear establishment. The next section takes the reader out of USTC to explore other broader attempts by Chinese biophysicists to mobilize public support for radiobiology.

\section{Radiobiology and atmospheric nuclear tests}

In the summer of 1962, the US launched a high-altitude nuclear weapon test some 250 miles above the Pacific Ocean. ${ }^{15}$ Led by the US Department of Defense, "Operation DOMINIC I" triggered outrage among the Chinese scientific community, with prominent Chinese scientists such as Bei Shizhang offering their own scathing commentaries on the event. Bei was featured in an op-ed piece on People's Daily, inveighing against the American "imperialists" for their "barbaric" action in total disregard for the safety and wellbeing of the rest of the world:

That American imperialists ignore the opposition from people all over the world and conduct a barbaric nuclear blast

\footnotetext{
${ }^{15}$ Operation DOMINIC I was a series of 36 atmospheric nuclear weapons detonations held in the Pacific Ocean from April to November in 1962. It included five high-altitude shots at Johnston Island, twenty-nine airburst events near Johnston and Christmas Island, one Polaris-launched airburst in the Christmas Island, and one underwater test in the Pacific Ocean off the US West Coast. Operation DOMINIC II was comprised of continental nuclear tests. Operations DOMINIC I \& II were the last series of atmospheric nuclear weapons tests conducted by the US for the purpose of weapons development through studying nuclear detonations as a defense against ballistic missiles. See Berkhouse (1983) for an official report prepared by the US Department of Defense.
} 
in space is a sign of their outrageous preparation for a nuclear war. We know that a nuclear explosion in space endangers not just a country or a region but the entire globe. One can see clearly now that it is American imperialism that poses a threat to world peace. To defend world peace and to fight for happiness for humanity, we are raising the strongest protest against American imperialism. (People’s Daily 1962)

Bei's acerbic criticism of "Operation DOMINIC I" reflects the stakes involved in a biophysicist's public entanglement with nuclear politics. Although Bei Shizhang was the lead scientist (with his name featured prominently alongside the headline), two other scientists also contributed to the same article. Zhao Jiuzhang, director of the CAS Institute of Geophysics, and Lin Rong, deputy chairman of the Biological Academic Division. Zhao Jiuzhang also criticized the US "imperialist" action, describing the nuclear blast in the upper-atmosphere as a hundred times more powerful than the Hiroshima bomb. The electromagnetic pulse resulting from the nuclear explosion created an artificial radiation belt that significantly reduced the shielding of the Earth from solar radiation. The highaltitude explosions exposed the hypocrisy of the US claims regarding the "peaceful use of outer space."

The Institute of Geophysics under Zhao Jiuzhang's leadership was, alongside Bei Shizhang and the IBP, another CAS team that was in charge of the sounding rocket mission. The geophysical sounding rocket series predated the biological sounding rocket series in the launch history of T-7 rocket flights. The first geophysical sounding rocket was fired in 
February 1960, but the first biological sounding rocket prototype was not ready until 1963 (Luk 2015a). In many ways, Zhao had more expertise and experience than Bei on the topic of nuclear space bursts and hazards, as demonstrated by his more fact-based illustrations of the effects of nuclear detonation and radioactive fallout on atmospheric integrity.

The other scientific figure contributing to this article, Lin Rong, was deputy chairman of the Biological Academic Division and associate director of the Institute of Botany at CAS. In the news report, Lin condemned the "crazy" behavior of the US on the grounds that the nuclear tests affected the natural habitat on earth by wrecking the ionosphere. As veteran biologists, Lin and Bei were among the first fifty academicians to be elected to the Biological Academic Division of CAS in 1955 (Xue and Ji 1996).

Compared to the two other scientists featured in the critique of Operation DOMINIC I, Bei's criticism was the most outstanding. Zhao's rebuke related mostly to the technical damage of nuclear hazards, whereas Lin's reprimand was confined to merely one sentence. The article presented Bei as the spokesman for atmospheric radiology. His public stance in People's Daily reflected his continued interest in promoting radiobiology as a legitimate field and career for biophysicists. Immediately after the sounding rocket operations were included in the Chinese "Two Bombs, One Star" project, Zhao and Bei appeared in a news article praising the Soviet efforts in pioneering high-altitude space travel with dogs and rabbits (People's Daily 1959). A large part of the 1959 article was dedicated to Zhao's comment on the technological advances of Soviet rocketry in terms of their propulsion power, payload-carrying capacities, and the types of scientific instruments they carried for measuring ionospheric components and cosmic radiation. Bei's smaller contribution to the same article underlined the Soviet accomplishment of carrying 
biological passengers and specimens on suborbital flights, commending the tremendous scientific value of these cosmobiological missions for supplying the requisite data to further the studies of space biology. His claim was that "such a great scientific achievement could only take place in socialist countries." (People's Daily 1959)

One might ask how much of this journalistic analysis was a result of top-down decisions from the newspaper's editorial office or bottom-up campaigning from individual scientists. Although it is not clear to what extent Bei's prominence in these news discourses was a result of his own efforts, rather than the result or other unknown factors, his desire to promote the work of biophysicists in radiobiology can be discerned from other sources. He organized the "National Radiobiology Workshop" in Beijing between February 7 and 11 in 1960. As the convener and member of the "steering committee of the national radiobiology research," he reported on the current state of research in radiobiology, in addition to issuing a "National Blueprint on Radiobiology and Radiotherapy Research." Three years after this agenda-setting workshop, the National Defense Science and Technology Commission coordinated a "National Radiobiology and Radiotherapy Academic Exchange Conference" between 28 August and 12 September 1963. The conference organizing committee received a total of 693 papers from all over the country, attesting to the national mobilizing impact of the 1960 workshop that Bei had put together (IBP-CAS 2012).

For the 1963 conference, Bei's delivered a closing speech entitled "Current Status and Prospects of Radiobiology and Radiotherapy in Our Country," in which he reviewed the short history of radiobiology and radiotherapy in the PRC as measured against the international benchmark. He compared the number of research papers submitted to the 1963 conference with the average number of publications contained in two major 
radiobiology academic abstracting services at the time, Nuclear Science Abstracts and Excerpta Medica, in order to evaluate the advances that China had made in the field of radiobiology between 1960 and 1963. The 684 papers, averaging some 300 papers per year, accounted for about one-tenth of the 3600 and 3000 articles indexed in NSA and EM respectively in 1962. His preliminary bibliometric analysis of the quantity and quality of Chinese publication in radiobiology and radiotherapy accentuated not just China's share of the world's research output but also the qualitative distinctiveness of Chinese efforts in these areas. As Bei argued, "Compared with international research, not only does the development of radiobiology and radiotherapy in our country cover a more comprehensive scope, a balance is also maintained among the five research areas." (Wang 2010: 231) The five research areas he referred to were radiation therapy, radiation hygiene, radiation dosimetry, radiation measurement, and the biomedical applications of isotopes. Bei valued the notion of a certain balance between disciplines, as he followed a holistic view of science which emphasized the interplay between wholes and parts:

It is imperative to possess a holistic concept to study living organisms. But judging from the present level of technical capability, it is difficult to penetrate and solve problems if we only limit ourselves to studying the whole organisms without using in vitro experiments as supplements. The connections between wholes and parts, macro and micro, and structures and functions, are the three aspects of the basic patterns of living behaviors. (Wang 2010: 232) 
In his tireless campaign to promote new disciplinary interests - in this case, radiobiology Bei maintained a basic commitment to a organism-centered conception of disciplinary configuration. His primary interest in understanding living organisms does not preclude invasive experimental methodology in favor of a vitalistic approach for preserving the integrity of the organism. A holistic view of nature does not necessarily translate into an obstinate opposition to new technology and methodology for more precise mechanical demonstration. It simply means a more balanced and systematic approach that seeks to relate those new methods with other disciplines within a broader purview of the life sciences.

Bei's systematic thinking was reflected in his comprehensive efforts to promote radiobiology as a subset of biophysics. His political rhetoric on People's Daily and his national conference-organizing endeavors were matched by his educational campaign at USTC, where he sought to reaffirm the contribution of biophysics to national defense via radiobiology and cosmobiology:

Certain areas in the terrain of biophysics have direct impact on the development of other disciplines. For example, research in radiobiology not only offers efficacious prophylactic and diagnostic measures in radiation-related illnesses, but also facilitates the further development of the nuclear industry. Meanwhile, research in cosmobiology paves the way for manned space exploration and contributes 


$$
\begin{aligned}
& \text { to inter-planetary flight service. Therefore, building this } \\
& \text { program (biophysics) is of paramount importance. }{ }^{16}
\end{aligned}
$$

In this document, Bei argued for the significance of biophysics from the standpoint of both radiobiology and cosmobiology. The radiobiology connection to the military service was a timely venture to anchor the biophysics outpost at USTC. "Operation DOMINIC I" came at a critical moment, as concerns over radioactive fallout merited public outcry and scientific intervention. It is not an overstatement to suggest that radiobiology benefited enormously from the national security concerns over the 1962 US atmospheric nuclear weapon test. Considering the widespread impact of foreign nuclear weapons tests on China's nuclear program, radiobiology was riding upon the strategic coattails of the Chinese militarynuclear establishments. Investigations into the biological hazards of high-altitude radiation were directly related to the opportunities and challenges for doing civilian radiobiology amid the military bomb operation scheduled for detonation at the Lop Nor testing area in Xinjiang on 16 October 1964.

The opportunities to pursue clinical radiobiology were driven by the security concern over the long- and near-term hazards of radioactive fallout. The 1962 atmospheric test over the Pacific Ocean - the very incident that drew Bei's critical attention - shaped the evolution of the radiobiology program in subsequent years. Following the People's Daily public condemnation, a radiobiology research unit was set up at the Lop Nor testing site under Bei's directorship. Commissioned by the People's Liberation Army (PLA), the

\footnotetext{
16 “Adjustment Plan for Seven Departments and Specialized Groups (Classified)," Office of University Archive, USTC, Box 1963-WS-Y-33.
} 
unit was in charge of studying the effects of radiation on living organisms. While PLA commanders were perturbed by the US military doctrine of nuclear deterrence and disarmament, Chinese biophysicists were increasing their commitment to radiation-related biomedical research (IBP-CAS 2012). Although the PLA did not maintain an explicit nuclear strategy until the late 1970s and early 1980s (Lewis and Xue 2012), the PLA-led military interests overlapped with the biophysicist-coordinated civilian interests in the atomic program at the crossroads of radiobiology. The Military Medical Science Academy was responsible for measuring the near-term, high-dose exposure to radiation in the human body, whereas the radiobiology research taskforce at IBP oversaw the long-term, low-dose effects of radiation on biological subjects. While the military officers and flight surgeons examined the immediate (and more catastrophic) short-term effects of atomic detonation, biophysicists at IBP studied the effects of the continuing accumulation of radioactive materials. In this context, experiments on the biological effects of ionizing radiation tended to rank high on the biophysics research agenda.

At the Lop Nor testing site in Xinjiang, 23 atmospheric nuclear weapons tests were conducted between 1964 and 1996 (after 1976 all tests were conducted underground). As members of "Mission 21," Chinese biophysicists took part in six on-site animal experiments during the atmospheric nuclear blasts. Table 2 details the biophysicists' involvement in China's atmospheric nuclear weapons tests:

As Table 2 shows, all of the on-site radiobiology experiments performed by the biophysicists involved exposing mammals (dogs, rats, monkeys, rabbits) to radiation 
dosage at some distance from the blast center. These animals were then brought back to the laboratory for health monitoring and inbreeding, followed by dissection, to ascertain the medical and genetic effects of the radiation to which they had been exposed. Experimental methodology includes clinical observations, mortality rates, tumor rates, selective breeding experiments, bone marrow and hemoglobin distribution and morphology, etc. For those animals that were kept alive for control studies, observation and monitoring continued for some ten years after the on-site experiments, cutting across the Cultural Revolution. In fact, the Cultural Revolution seems to have exerted little impact on the radiobiology research, as all six radiobiology experiments took place during the Cultural Revolution between 1966 and 1976.

Table 2 also shows that Chinese biophysicists who warned against the dangers of the US atmospheric nuclear tests were complicit in China's atmospheric nuclear tests conducted on Chinese territory. It is worth mentioning that there were different sets of goals pursued by various parties involved in these nuclear tests. For the military commanders, the prospect of guarding China against the nuclear threat from the US was of utmost importance. For the Chinese scientists, the ideology of nuclear deterrence by possessing nuclear weapons for minimum retaliation was equally significant. The nuclear threat from the US served as a strong justifying narrative for many Chinese scientists and engineers in their cooperation with the military sector. It was in these circumstances that the Chinese biophysicists who had criticized the US atmospheric nuclear tests as "barbaric" and "imperialistic" ended up involving in similar tests themselves, for these domestic efforts were regarded as a means to serve the country, and to protect its people from both US aggression and the problems associated with exposure to radiation. 
Following the atmospheric nuclear weapons tests carried out by the PRC on 26 September and 17 November 1976, the Environmental Radiation Ambient Monitoring System operated by the Office of Radiation Program under the US Environmental Protection Agency (EPA) was activated to monitor the health effects of the radioactive fallout from these tests on the US population. The EPA assessment report noted that no significant radioactivity levels were expected but since both nuclear detonations were above ground, there was a risk that the radioactive debris injected into the atmosphere could spread to US territory, potentially contaminating milk and other foodstuffs (Strong et al. 1977). The EPA report expressed the same fears about radioactive exposures caused by atmospheric nuclear weapons tests on US populations, as the US tests had earlier prompted from Chinese scientists for their own population. Radiation exposure was a shared concern for both governments and initiatives to reduce civilian exposure to airborne radiation pollution were gradually gaining momentum. For the US and its allies, this effort was partly reflected in the authorization of the Limited Test Ban Treaty of 1963, which banned all atmospheric testing of nuclear weapons except nuclear explosions for "peaceful purposes." In spite of this partial moratorium on nuclear weapons tests, the 1963 treaty did little to alleviate the sustained concerns over long-term radiation contamination. As de Chadarevian suggested, "In many respects the test ban treaty of 1963 marked the end of the fallout debate, but the question of the long-term effects of low-dose radiation persisted" (De Chadarevian 2006: 728). The role of Chinese biophysicists' in measuring the lasting effects of low-dose radiation revealed the often invisible dangers radiation posed to the civilians as well as to the military officers. 


\section{Conclusion}

China continued to conduct nuclear weapons tests until it became a signatory to the Comprehensive Nuclear Test Ban Treaty in 1996, although it has yet to ratify the Treaty. China's final atmospheric nuclear test on 16 October 1980 was also the world's last recorded surface nuclear test. As shown by the Scientific American report of 2009, cited in the introduction, the impact of China's atmospheric nuclear tests on the affected population in Xinjiang remains a politically-charged question. The image of ethnic Uyghurs choking on the radioactive dusts from China's nuclear weapons tests provides a powerful coda to the current analysis. According to one estimate, the peak radiation dose in Xinjiang during the 1960s and 1970s exceeded the level of radiation from the Chernobyl accident in 1986 (Takada 2004). Yet the more far-reaching risks of radiation exposure to human populations remain obscure. As late as 2014, a NAS report on radiobiology continued to stress the uncertainty surrounding the biological effects of exposure to low-dose ionizing radiation (IOM and NRC 2014).

A historical understanding of the emergence of radiobiology in China gives us a more complete account of the atomic story of the last century. Existing scholarship on the rise of radiobiology in post-war life sciences has tended to concentrate on atomic diplomacy and American hegemony, with radiobiology portrayed as a product of the Manhattan Project and the peaceful applications of atomic research. Less attention has been paid to the connection between China's radiobiology and the Chinese "Two Bombs, One Star" project. To make sense of the non-linear development of radiobiology in China, I started my analysis with the transnational flow of radium in the early 1920s. Mediated by the Rockefeller Foundation, the arrival of radium to Republican China coincided with 
regulatory intervention and wartime conditions of material shortage. The political transition from the Republic of China to the People's Republic witnessed the systematic institutionalization of science and technology. Within the nuclear science and technology enterprise, radiobiology was embedded in the military-industrial complex of strategic nuclear forces. The flourishing of Chinese radiobiology was prompted by both the disciplinary growth of radiobiology at USTC and the requirement for biophysicists' cooperation with the military in performing China's atmospheric nuclear weapons tests between 1964 and 1976. Their complicity in atmospheric nuclear tests was at odds with the public outrage they expressed against American atmospheric nuclear tests. The Chinese response to the American nuclear tests and the American response to the Chinese nuclear tests reflect not just a certain Cold War rivalry at play but more importantly a global narrative of scientific and technological affairs in the post-atomic age.

\section{References}

Bauer, S. et al. (2005). Radiation exposure due to local fallout from Soviet atmospheric nuclear weapons testing in Kazakhstan: solid cancer mortality in the Semipalatinsk historical cohort, 1960-1999. Radiation Research 164, 409-419

Berkhouse, L. et al. (1983). Operation DOMINIC I, 1962. Springfield, VA: National Technical Information Service.

Bo, W. L. (2001). Chuang Zao Qi Ji de Renmen: Zhongguo ‘Liangdan Yixing' Yuan Xun (The People Who Created Miracles: China's “Two Bombs, One Star” Pioneers). Wuhan: Hu Bei Jiao Yu Chu Ban She. (In Chinese) 
Bromley, A. and Perrolle, P. M., eds. (1980). Nuclear Science in China (CSCPRC Report No. 10). Washington, DC: National Academy Press.

Campos, L. (2015). Radium and the Secret of Life. Chicago: University of Chicago Press.

Creager, A. (2002). Tracing the politics of changing postwar research practices: the export of 'American' radioisotopes to European biologists. Studies in the History and Philosophy of the Biological and Biomedical Sciences, 33(3): 367-388.

Creager, A. (2006). Nuclear energy in the service of biomedicine: The US atomic energy commission's radioisotope program, 1946-1950. Journal of the History of Biology, 39(4), $649-684$.

Creager, A. (2014) Life Atomic: A History of Radioisotopes in Science and Medicine (Synthesis). Chicago: University of Chicago Press.

Creager, A. and Santesmases, M. J. (2006). Radiobiology in the atomic age: changing research practices and policies in comparative perspective. Journal of the History of Biology, 39(4), 637-647.

De Chadarevian, S. (2006). Mice and the reactor: the 'Genetics Experiment' in 1950s Britain. Journal of the History of Biology, 39(4), 707-735.

Dimoia, J. (2010). Atoms for sale?: Cold War institution-building and the South Korean 
atomic energy project, 1945-1965. Technology and Culture 51(3), 589-618.

Dong, S. (2007). Tian Di Song - 'Liangdan Yixing' Bai Nian Jie Mi (Gong San Ce) (In Praise of the Heaven and Earth: Revealing Hundred Years of Secret of 'Two Bombs, One Star') (Vols. 1-3). Hua Xia Chu Ban She. (In Chinese)

Environmental Protection Agency (2007). Ionizing Radiation: Fact Book. http://www.epa.gov/radiation Accessed 25 July 2015.

Ferguson, M. F. (1970). China Medical Board and Peking Union Medical College: A Chronicle of Fruitful Collaboration, 1914-1951. New York: China Medical Board of New York.

Gaudilliere, J. (2006). Normal pathways: controlling isotopes and building biomedical research in postwar France. Journal of the History of Biology, 39(4), 737-764.

Institute of Biophysics-Chinese Academy of Sciences (IBP-CAS), ed. (2012). Mo gu yun bei hou: Fang she sheng wu xue si shi nian yan jiu ji shi (Behind the Mushroom Cloud: A Documentation of Forty Years of Research in Radiobiology). Beijing: Science Press. (In Chinese)

Institute of Medicine (IOM) and National Research Council (NRC) (2014). Research on Health Effects of Low-level Ionizing Radiation Exposure: Opportunities for the Armed Forces Radiobiology Research Institute. Washington, DC: The National Academies Press. 
http://www.nap.edu/catalog.php?record_id=18732 Accessed 25 June 2015.

Krige, J. (2005). The politics of phosphorus-32: a Cold War fable based on fact. Historical Studies in the Physical and Biological Sciences, 36(1), 71-91.

Krige, J. (2006). Atoms for peace, scientific internationalism, and scientific intelligence. Osiris 21(1), 161-181.

Krige, J. (2008). The peaceful atom as political weapon: euratom and American foreign policy in the late 1950s. Historical Studies in the Natural Science 38(1), 5-44.

Leslie, S. (2015). Atomic structures: the architecture of nuclear nationalism in India and Pakistan. History and Technology 31(3), 220-242.

Lewis, J. and Xue, L.T. (1988). China Builds the Bomb. California: Stanford University Press.

Lewis, J. and Xue, L.T. (1994). China's Strategic Seapower: The Politics of Force Modernization in the Nuclear Age. California: Stanford University Press.

Lewis, J and Xue, L.T. (2012). Making China's nuclear war plan. Bulletin of the Atomic Scientists 68(5), 45-65. 
Li, X. (2000). Gong He Guo de Ji Liang: 'Liangdan Yixing' Gong Xun Pu (The Backbone of the Republic: 'Two Bombs, One Star' Honor Roll). Haerbin: Hei Long Jiang Jiao Yu Chu Ban She. (In Chinese)

Luk, C. Y. L. (2015a). A History of Biophysics in Contemporary China. Dordrecht: Springer.

Luk, C. Y. L. (2015b). "Building biophysics in mid-century China: The University of Science and Technology of China" Journal of the History of Biology 48(2), 201-235.

Luk, M. Y. L. (1990). The Origins of Chinese Bolshevism: An Ideology in the Making, 1920-1928. Hong Kong: Oxford University Press.

Mateos, G. and Suárez-Díaz, E. (2015). 'We are not a rich country to waste our resources on expensive toys': Mexico's version of Atoms for Peace. History and Technology 31(3), $243-258$.

Merali, Z. (2009). Blasts from the Past: Did China's Nuclear Tests Kill Thousands and Doom Generations? Scientific American July 2009, 16-20.

People's Daily (1959). Wo guo ke xue jia zhao jiu zhang, bei shi zhang zhi chu, su lian gao kong huo jian shi zhong da de chuang zao (Scientists in Our Country, Zhao Jiuzhang and 
Bei Shizhang, Pointed to the Soviet High-Altitude Rocket Flights as an Important Creation) People’s Daily, July 9, 1959.

People's Daily (1962). Wo guo ke xue jia bei shi zhang deng fa biao tan hua, nu qi mei guo jia jin zhun bei he zhan zheng (Scientists in Our Country such as Bei Shizhang and Others Spoke Out Angrily against the United States for Scaling Up on Preparing a Nuclear War). People’s Daily, July 13, 1962.

Phalkey, J. and Wang, Z. Y. (2016). Planning for science and technology in China and India. British Journal for the History of Science Themes 1, 83-113.

Rader, K. (2006). Alexander Hollaender's postwar vision for biology: Oak Ridge and beyond. Journal of the History of Biology, 39(4), 685-706.

Reed, T. (2008). The Chinese Nuclear Tests, 1964-1996. Physics Today, 61(9), 47-53.

Rosenbaum, T. (1988). The archives of the China Medical Board and the Peking Union Medical College at the Rockefeller Archive Center. Journal of East Asian Libraries, $84(4): 5-19$

Santesmases, M. J. (2006). Peace propaganda and biomedical experimentation: influential uses of radioisotopes in endocrinology and molecular genetics in Spain (1947-1971). Journal of the History of Biology, 39(4), 765-794. 
Strong, A. et al. (1977). EPA Assessment of Fallout in the United States From Atmospheric Nuclear Testing on September 26 and November 17, 1976 by the People's Republic of China. Washington, DC: EPA.

Takada, J. (2004). Nuclear Hazards in the World: Field Studies on Affected Populations and Environments. Kodansha: Springer.

Wang, G. Y. (2010). Bei shi zhang zhuan (A Biography of Bei Shizhang). Beijing: Science Press. (In Chinese)

Wang, Z. Y. (2015). The Chinese developmental state during the Cold War: the making of the 1956 twelve-year science and technology plan. History and Technology, 31(3), 180205.

Xue, P. G. and Ji, C. Q., eds. (1996). Zhong guo ke xue yuan shi liao hui bian (1953-1955) A Compiled and Edited Historical Materials of the Chinese Academy of Sciences (19531955) Beijing: Zhong guo ke xue yuan yuan shi wen wu zi liao zheng ji wei yuan hui ban gong shi. (In Chinese)

Zhang, Z. H. and Liu, P. (2015). Gai ge kai fang chu qi zhong guo fang she hua xue zhuan xing de chang shi: guan yu fang she hua xue xue ke gui hua zhi ding ji zhuan ye xue hui cheng li de kao cha (Attempts at transforming radiochemistry in the early reform period: 


\begin{abstract}
About the promulgation of the "radiochemistry disciplinary plan" and the assessment of the formation of the professional society) Ke Xue Wen Hua Ping Lun 12(1): 55-68. (In Chinese)
\end{abstract}


Table 1. The 1960 radiobiology syllabus at USTC

\begin{tabular}{|c|c|c|}
\hline \multicolumn{2}{|c|}{ Unit } & Chapter \\
\hline & \multirow[t]{2}{*}{$\begin{array}{l}\text { The physical foundation of } \\
\text { radiobiology }\end{array}$} & $\begin{array}{l}\text { 1. The production of ionizing radiation and its functions on substance } \\
\text { 1.1 The nature and production of ionizing radiation } \\
\text { 1.2 Ionizing radiation and its functions on substance }\end{array}$ \\
\hline & & $\begin{array}{l}\text { 2. Basic concepts of dosimetry of ionizing radiation } \\
2.1 \text { Dosage unit of ionizing radiation } \\
2.2 \text { Dosimetry-related knowledge }\end{array}$ \\
\hline \multirow[t]{5}{*}{ II. } & \multirow{5}{*}{$\begin{array}{l}\text { Biological mechanism of } \\
\text { ionizing radiation }\end{array}$} & 3. Basic principles of radiation effects \\
\hline & & 4. Radiation-induced ionization: Radicals \\
\hline & & 5. Stimulating effects \\
\hline & & 6. Effects of ionizing radiation on structures: target theory \\
\hline & & 7. About primary effect mechanism \\
\hline & \multirow[t]{4}{*}{ Radiation biochemistry } & $\begin{array}{l}\text { 8. Radiation chemistry of ionizing radiation's effects on water and } \\
\text { solvents } \\
\text { 8.1 Direct and indirect effects of ionizing radiation } \\
8.2 \text { General concepts of water ions }\end{array}$ \\
\hline & & $\begin{array}{l}\text { 9. Effects of ionizing radiation on polymers } \\
\text { 9.1 Effects of radiation on synthetic polymers } \\
\text { 9.2 Effects of radiation on protein macromolecules } \\
\text { 9.3 Effects of radiation on enzymes } \\
\text { 9.4 Effects of radiation on nucleic acid and protein } \\
\text { 9.5 Effects of radiation on lipoid }\end{array}$ \\
\hline & & $\begin{array}{l}\text { 10. Impacts of ionizing radiation on metabolism } \\
\text { 10.1 Impacts of radiation on glucose metabolism } \\
\text { 10.2 Impacts of radiation on fat metabolism } \\
\text { 10.3 Impacts of radiation on protein and nitrogen metabolism } \\
\text { 10.4 Interference of radiation on enzymes and enzyme systems } \\
\text { 10.5 Effects of radiation on lipoid } \\
\text { 10.6 Impacts of radiation on nucleic acid and protein metabolism } \\
\text { 10.7 Impacts of radiation on basic metabolism and mineral } \\
\text { metabolism }\end{array}$ \\
\hline & & $\begin{array}{l}\text { 11. Impacts of ionizing radiation on oxidative phosphorylation and } \\
\text { phosphorylation } \\
\text { 11.1 Impacts of radiation on mitochondria oxidative } \\
\text { phosphorylation } \\
\text { 11.2 Impacts of radiation on cellular nuclei's phosphorylation }\end{array}$ \\
\hline & \multirow{10}{*}{$\begin{array}{l}\text { Effects of ionizing radiation } \\
\text { on living organisms }\end{array}$} & 12. Impacts of ionizing radiation on skin and skin derivatives \\
\hline & & 13. Impacts of ionizing radiation on eyes \\
\hline & & 14. Impacts of ionizing radiation on hematopoiesis \\
\hline & & 15. Impacts of ionizing radiation on blood \\
\hline & & 16. Impacts of ionizing radiation on gonad \\
\hline & & 17. Impacts of ionizing radiation on digestive tract \\
\hline & & 18. Impacts of ionizing radiation on respiratory system \\
\hline & & 19. Radiation effects on the excretory system \\
\hline & & 20. Radiation effects on the endocrine system \\
\hline & & 21. Impacts of ionizing radiation on nervous system \\
\hline & $\begin{array}{l}\text { Effects of radiation on cells } \\
\text { and embryos, and radiation } \\
\text { genetics }\end{array}$ & $\begin{array}{l}\text { 22. Impacts of ionizing radiation on cells } \\
22.1 \text { Impacts of ionizing radiation on cellular morphology } \\
22.2 \text { Impacts of ionizing radiation on cellular chemistry } \\
22.3 \text { Impacts of ionizing radiation on cellular physiology }\end{array}$ \\
\hline
\end{tabular}


23. Impacts of ionizing radiation on animal embryos

23.1 Impacts of ionizing radiation on (male) gametes

23.2 Impacts of ionizing radiation on (female) gametes

23.3 Impacts of ionizing radiation on embryos and fetuses

24. Radiation genetics

24.1 Reproduction and genetics

24.2 General principles of radiation genetics

24.3 Impacts of ionizing radiation on genetics

24.4 Radiation/mutation breeding

VI. Protection against ionizing

25. Protection against ionizing radiation radiation and experimental diagnosis, treatment, and 25.1 Physical protection

recovery of radiation sickness

25.2 Chemical protection

25.3 Biological protection

25.4 Physical protection against ionizing radiation

25.5 Comparative study of radiation sensitivity

26. Experimental diagnosis, treatment, and recovery from radiation sickness

26.1 Symptoms and critical pathological and physiological

changes in radiation sickness

26.2 Diagnosis of radiation sickness

26.3 Experimental therapy for radiation sickness

VII. Radiation ecology and Preface

1. Historical background of radiation ecology

2. Research missions of radiation ecology

3. Radiation ecology and its relationship with other disciplines

27. Natural sources and distribution of ionizing radiation in nature

27.1 Cosmic rays

27.2 Radioactivity in soil, air, and water

27.3 Natural radiation levels in living organisms

27.4 Effects of natural ionizing radiation on organisms

28. Nuclear weapons and the dissemination of blast fallouts

28.1 Nuclear weapons

28.2 Radioactive materials from nuclear weapons explosions

28.3 Precipitation and dissemination of radioisotopes

28.4 Accumulation and transmission of radioisotopes

29. Environmental pollution and hazards of radioactive strontium

29.1 Atmospheric distribution and precipitation of $\mathrm{Sr}-90$

29.2 Sr-90's contamination of soil and water sources

29.3 Sr-90's contamination of plants and food

29.4 Sr-90's level in human bones

29.5 Transmission process of Sr-90 to human food chain

29.6 Potential hazards of incessant nuclear weapons tests

30. Caesium-137, iodine-131, and other radioactive materials from nuclear blasts

30.1 Cs- 137

30.2 Radioactive iodine

30.3 Radioactive holmium-140

30.4 Other scattered radioactive elements

30.5 Induced radioactive elements

30.6 Remains of unreacted uranium, plutonium, and tritium

31. Concentration distribution and transfer of radioactive elements among aquatic animals

31.1 Radioactivity in the ocean

31.2 Absorption means of isotopes among aquatic animals 
31.3 Absorption and accumulation of isotopes among fish

32. General nature of radioactive substance and their means of entering living organisms

32.1 General nature of radioactive substance

32.2 Radioactive substance's means of entering living organisms

33. Bodily distribution of radioactive substance

33.1 General principles of bodily distribution of radioactive substance

33.2 Factors affecting the distribution of radioactive substance

34. Metabolism and discharge of radioactive substance from the body

34.1 Metabolic regularity of radioactive substance in the body

34.2 Status of radioactive substance after entering the body

34.3 Means of releasing radioactive substance from the body

34.4 Changes in the discharge amount of radioactive substance

34.5 Half-discharge period

35. Characteristics of radiation injury

35.1 Characteristics of irradiation injury

35.2 Irradiation-induced pathological process

35.3 Late-effects of radiation damage

35.4 Toxicology of radioactive strontium

35.5 Toxicology of uranium

35.6 Toxicology of radon

36. Artificially accelerated discharge of radioactive substance

36.1 Use of complexing agent

36.2 Functional status of affected organism

36.3 Effects on bone metabolism

36.4 Control of nutritious content

36.5 Application of ammonium chloride

(Source: "An overview of the teaching of 'radiobiology' at the department of biophysics at

USTC," in IBP-CAS 2012, pp. 292-294) 
Table 2. Radiobiology experiments conducted at China's atmospheric nuclear weapons tests, 1964-1976

\begin{tabular}{|c|c|c|}
\hline Date & Test type & Radiobiology experiments \\
\hline 16 October 1964 & Atomic bomb detonation & $\begin{array}{l}4 \text { dogs exposed to } 149 \mathrm{rad}(1 \\
\mathrm{rad}=0.01 \mathrm{~Gy}) \text { radiation dose at } \\
1500 \mathrm{~m} \text { away from the explosion } \\
\text { epicenter }\end{array}$ \\
\hline 14 May 1965 & Atomic bomb detonation & $\begin{array}{l}6 \text { dogs exposed to } 344-409 \mathrm{rad} \\
\text { radiation dose at } 600 \mathrm{~m}, 800 \mathrm{~m} \text {, } \\
\text { and } 1400 \mathrm{~m} \text { away from the } \\
\text { explosion epicenter; } 266 \text { rats, and } \\
132 \text { mice exposed to } 301-440 \mathrm{rad} \\
\text { and } 50-310 \text { rad radiation doses } \\
\text { respectively at } 834-3090 \mathrm{~m} \text { away } \\
\text { from the explosion epicenter }\end{array}$ \\
\hline 9 May 1966 & $\begin{array}{l}\text { Boosted-fission, airdropped device } \\
\text { test }\end{array}$ & $\begin{array}{l}20 \text { dogs and } 350 \text { rats exposed to } \\
90-25 \text { rad radiation dose at } 1600- \\
2000 \mathrm{~m} \text { away from the explosion } \\
\text { epicenter; } 11 \text { rabbits for } \\
\text { irradiation study }\end{array}$ \\
\hline $\begin{array}{l}28 \text { December } \\
1966\end{array}$ & Hydrogen bomb experimental test & $\begin{array}{l}14 \text { dogs exposed to } 150-100 \mathrm{rad} \\
\text { radiation dose at } 1900-2000 \mathrm{~m} \\
\text { away from the explosion } \\
\text { epicenter; } 28 \text { rabbits feeding on } \\
\text { radioactive fallout debris }\end{array}$ \\
\hline
\end{tabular}




\begin{tabular}{|c|c|c|}
\hline $\begin{array}{l}18 \text { November } \\
1971\end{array}$ & $\begin{array}{l}\text { Plutonium-filled atomic bomb } \\
\text { detonation }\end{array}$ & $\begin{array}{l}30 \text { dogs exposed to } 49-173 \mathrm{rad} \\
\text { radiation dose at } 1200-10500 \mathrm{~m} \\
\text { away from the explosion } \\
\text { epicenter; } 14 \text { adult monkeys and } \\
7 \text { baby monkeys exposed to } 42- \\
74 \text { rad radiation dose at } 1400- \\
1500 \mathrm{~m} \text { away from the explosion } \\
\text { epicenter }\end{array}$ \\
\hline 23 January 1976 & 2 megaton nuclear warhead test & $\begin{array}{l}95 \text { dogs exposed to } 1-215 \mathrm{rad} \\
\text { radiation dose at } 800-8000 \mathrm{~m} \\
\text { away from the explosion } \\
\text { epicenter; } 19 \text { adult monkeys and } \\
22 \text { baby monkeys exposed to } 42- \\
117 \text { rad radiation dose at } 1000- \\
1200 \mathrm{~m} \text { away from the explosion } \\
\text { epicenter; } 43 \text { dogs, } 28 \text { monkeys } \\
\text { and } 42 \text { rats for control studies }\end{array}$ \\
\hline
\end{tabular}

(Source: "Appendix: major events related to radiobiological research at IBP-CAS" in IBP-CAS 2012, pp. 310-333) 